Article

\title{
Does the Role of Media and Founder's Past Success Mitigate the Problem of Information Asymmetry? Evidence from a UK Crowdfunding Platform
}

\author{
Sardar Muhammad Usman 1,2 (D), Farasat Ali Shah Bukhari ${ }^{1,2}$, Muhammad Usman ${ }^{3,4, *}$, \\ Daniel Badulescu ${ }^{5}$ (D) and Muhammad Safdar Sial ${ }^{2}$ \\ 1 School of Management, Zhejiang University, Hangzhou 310058, China; 11620072@zju.edu.cn (S.M.U.); \\ 11620074@zju.edu.cn (F.A.S.B.) \\ 2 Department of Management Sciences, COMSATS University Islamabad (CUI), Islamabad 44000, Pakistan; \\ safdarsial@comsats.edu.pk \\ 3 Division of Computational Mathematics and Engineering, Institute for Computational Science, \\ Ton Duc Thang University, Ho Chi Minh City 700000, Vietnam \\ 4 Faculty of Finance and Banking, Ton Duc Thang University, Ho Chi Minh City 700000, Vietnam \\ 5 Department of Economics and Business, Faculty of Economic Sciences, University of Oradea, 410087 Oradea, \\ Romania; dbadulescu@uoradea.ro \\ * Correspondence: usman@tdtu.edu.vn
}

Received: 8 December 2018; Accepted: 24 January 2019; Published: 28 January 2019

check for updates

\begin{abstract}
Crowdfunding is an innovative concept for a new start-ups seeking financial support for their distinctive and novel projects. Despite their popularity, crowdfunding platforms face several key challenges amongst which is information asymmetry between entrepreneurs and influential backers, where credible information must be disclosed by the founders (entrepreneurs) to the potential "backers" in order to assess the potentiality of the project. In order to fill this gap, we developed and tested a model that examines the signaling interaction between the founder and a potential backer through media and the founders' past success. This model also examines how these two signals (i.e., media and past success) interact so as to mitigate the problem of information asymmetry and to make the project successful. A total of 14,887 projects were extracted from a reward-based platform named Crowdfunder. The data was analyzed by performing Tobit and logistic regression and the model was validated by using the robustness technique. The results strongly mitigate the problem of information asymmetry which improves the rate of success in projects floated on the Crowdfunder platform. We believe that our study will significantly contribute to this nascent yet developing research area by probing for information mechanisms to succeed in crowdfunding.
\end{abstract}

Keywords: entrepreneurs; information asymmetry; Crowdfunder; backers; founders' past success; role of media; signaling; United Kingdom

\section{Introduction}

At the preliminary stages of development, most entrepreneurial ventures need to seek an alternative source of financing due to resource constraints and the absence of proper mechanisms. Such requirements make it hard for the start-up to survive and grow [1,2]. Moreover, the structural difficulties inherent in start-up opportunities make it hard to attract external financing [3,4] In recent years, new forms of financing have gained traction, especially crowdfunding, which is defined as "allowing individual investors an opportunity to pool relatively small amounts of money together to meet the funding requirements of new or expanding ventures" [5] (p. 10). According to Schwienbacher and Larralde [6] crowdfunding is like an open call on the Internet through which project founders 
collect a reasonable contribution from a large number of backers. The enormous development of crowdfunding platforms provide a resilient opportunity for sustainable economic development [7]. Despite its popularity, crowdfunding faces several key challenges, one of them being the information asymmetry between founders and influential backers. This is because the project founder has more knowledge of the quality of the product/service while the backers have less information about the intellectual capital and credibility of the project founder [8]. Therefore, the founders must disclose credible information about the value proposition to the potential backers so that they can assess the potentiality of the crowdfunding projects [6]. Belleflamme et al. [9] compared two forms of crowdfunding and discussed the effect of information asymmetry in the choice of crowdfunding form. They concluded that in the presence of information asymmetry, the founders hold more private information related to the product description and quality than the backers. In such a situation, the potential backers prefer to finance the profit-earning scheme rather than pre-ordering so as to protect their financing. Kirmani and Rao [10] found that information asymmetry arose whenever there is a lack of information between the investors and the customers regarding the qualitative attributes of the firm. To alleviate this asymmetric information gap, the potential backers must determine the start-up attributes and the founder's actions that may reflect the prevailing quality of the start-up [11].

In crowdfunding, as compared to traditional financial instruments, transactions are mediated on platforms which increase the ambiguity of the relationship between backers and the founder [8]. This means that the relationship between backers and founders in crowdfunding can be evaluated through the principal-agent theory. According to Jensen and Meckling [12], a contractual agreement exists among a principal and an agent, and whenever a problem emerges, both partners reflect a different perspective of interest and thus information is being allocated asymmetrically between them. This means that the agent is holding more information and it is difficult for the principal to motivate the agent to perform on his/her behalf. In most crowdfunding platforms, the backers (acting as the principal) offers their financial support to the project founder (acting as the agent) in exchange for an attractive and adequate reward for their financing $[6,13]$.

This research examines the role of media and the founder's past success in the UK based crowd-funding market, which will enlighten the backers about the project success and help solve the problem of information asymmetry. This is likely to reflect the ability of a project to achieve the desired crowdfunding capital.

Research has highlighted that the inter-organizational relationship strengthens the third party endorsement; this serves as a good quality of signals for venture firms and will help in overcoming the information gap that exist between founders and backers [14]. Information intermediaries that act like a third party are: business press, consumer reports, and expert analysis and they can evaluate the availability of information about the start-up and its products [15].

Crowdfunding is currently in the incipient stages of development. The behavior and actions of the founders strongly amplify several essential factors such as project quality and founder credibility. These factors could help attract more potential backers and increase the success ratio of crowdfunding. Hornuf and Schwienbacher [16] examined German crowdfunding platforms and concluded that backers react to the information provided by the project founder and contribute more if the founder uses more valuable signals. One of the signals that could assist in achieving success is the use of media, such as video and images, through which the founder can communicate about the qualities of the product and stages of development [11]. Ahlers et al. [17] found that the creators used project pitches that consist of information regarding the project and product development, in the form of videos, text, images, product demo, and used external links for further information. Such pitches are used to convey signals aimed at resolving the pervasive information asymmetry among them and motivates potential backers to finance the project. 
Oba et al. [8] examined the relationship between platform reputation and the success of the project under the premise of value co-creation and information asymmetry. This explains what contributes to the success or failure of a project. They concluded that platform reputation, project quality, and entrepreneurial capacity of the project owners are strongly related with the success of a project. Vulkan et al. [18] found that initiating a project with strong determination is an important determinant for project success. Agrawal et al. [19] reported that members from family and peer group tend to contribute at initial stages and react slowly to other investors' decisions because they encounter low levels of information asymmetry compared to unknown finance providers. Besides this, other numerous studies also identify the problems caused by information asymmetry between founders and potential backers in crowdfunding settings [16,20-22].

The projects include video and image interpretation so as to show the development of the project and thus fulfilling the minimum preparation needed for the crowdfunding [20]. According to Bi et al. [23], projects having a video should be "a clear signal of minimum preparation" which leads towards a greater chance of success. The framework presented by Chen el al. [24] followed by Mollick [20] addresses the impact of quality preparation in motivating backers to finance new ventures. He confirmed that project quality signals significantly increase the chances of success.

Founder credibility and project quality are the two unique characteristics of start-ups. Such features act as potent signals for new start-up firms [25]. The potential backers mostly rely on the observable attributes of the start-up because detailed information about new start-ups is usually lacking [26]. Courtney et al. [11] suggested that crowdfunding experience differs from one founder to another. To evaluate the quality of the existing project, a potential backer can draw a meaningful inference by exploring the founders' past success. If the founder has more experience in managing and floating successful projects through crowdfunding, then backers strongly believe in the founders' credibility.

This study advances the models proposed by Courtney et al. [11] and Ngoc [25]. Courtney et al. claimed that large datasets (i.e., 267,295 projects) could make it hard to reach results that isolate the role of media. In such cases, measuring media as a strong signal is somehow imperfect to showcase a convincing performance. Whereas Ngoc argued that including a founder's quality indicator that reflects his/her past success reduces information asymmetry and stimulates confidence among backers. However, this does not apply to the reward-based crowdfunding model due to its low-risk nature and the fact that a product is the sole motive in reward-based crowdfunding. Given these conditions, our model incorporates the role of media and founder's past success by taking a sample size of 13,877 projects from a reward-based crowdfunding market, which seems more reasonable in comparison to a sample of 267,295 to test the role of media and founder's past success in mitigating the problem of information asymmetry and making it an acceptable signal.

To evaluate the quality of a project, potential backers pay more attention to the founders past successful campaigns. Previously, if a founder launched an attractive and successful campaign, it shows that the founder would deliver not only the promised rewards for the current project but it would also make this project more credible [17].

This study posits that the role of media and the founder's past success significantly mitigate the problem of information asymmetry and improves the rate of project success in the context of a reward-based crowdfunding market. Hence, both the variables constitute a positive signal for investment. 
Given the above arguments, the following research question is articulated:

\section{Does the level and type of used media and successful track record of previous projects influence the success/reward rate of crowdfunding campaigns?}

The remainder of the paper is organized in the following sections: Section 2 is related to the theoretical background and hypothesis development. Section 3 relates to the used data and applied methods. Section 4 describes the empirical findings, whilst Section 5 provides conclusions with implications for further research.

\section{Literature Review}

\subsection{Role of Information Asymmetry in Crowdfunding}

Crowdfunding faces exclusive information challenges due to the flow of funding within the limits of the online interface and limited time duration. At the nascent stage of development, uncertainties among the crowdfunding projects are very significant and prevalent $[17,20]$.

Information asymmetry plays a pivotal and often critical role as regards crowdfunding in most cases, where one party lacks information about the qualitative attributes of another party, or the project founder has considerably more information than the backer about the project's quality [27]. Backers understand that only a few projects are of good quality. In such situations, backers receive much less information and consider the founder's credibility unauthentic in regards to the promised product or service production and delivery $[20,28]$, albeit, the quality of the project largely depends on their market acceptability, feasibility, and viability, which remain unclear until the backers receive the product and experience its usage [11].

A founder's credibility goes together with trust, which potential backers expect from the founder regarding the promised production and delivery of products and services, as credibility and quality are two important aspects related to the functional and behavioral tendency of the founder [25].

Hornuf and Schwienbacher [29] identified explicit types of information. For example, updates provided to investors improve investment immensely as funders update their preferences in the light of project assessment. Moritz et al. [30] examined investor communication in equity crowdfunding, highlighting that perceived sympathy, openness, and trustworthiness in the relationship between venture and investor reduced perceived information asymmetries. They also explored that third-party communication influence on the decision-making process of backers. Moreover, allowing backers to adjust information about privacy and their contribution can deter some investors but increases the average contribution size [31].

Gangi and Daniele [32] analyzed the role of early-late backers and mentors in determining the success of crowdfunding campaigns. They evaluated these funders within the framework of information asymmetry and theory of signals. Based on data collected from an Italian reward-based platform, they concluded that both types of funders are remarkably important for the success of the crowdfunding campaign.

Market design plays a vital role in crowdfunding, which provides less information to the potential backers because they do not know how their financing efforts will be used for the project. Therefore, the primary source of information for the backers is the project description published by the creator on the crowdfunding platform [33]. The sources of information offered by the creator to the backer about the project are not enough to evaluate and understand the creator's real motive, determination, and trustworthiness about the project. On the contrary, venture capitalists and angel financers mostly meet with the entrepreneurs in person to avail the local investment because such a process is part of their due diligence [34]. The above scenario is very rare in crowdfunding which is neither acceptable nor feasible for the potential backers. Such a thing becomes an advantage for the creators as it enables them to overstate the quality of information in front of potential backers which is a disadvantage for the backers [35]. According to Akerlof [36], whenever there is a problem of information asymmetry 
between the founder and the backer, a question of adverse selection will arise, resulting in a financial transactions between the parties probably under inaccurate information. Secondly, for projects on crowdfunding platforms which are in their initial stages, given that most of the creators are young and inexperienced, this will imperfectly forecast project outcomes [37]. Third, the problem of moral hazard may arise [27], meaning that greater risks are being taken by the project creator because they are unaware of the legal consequences if they do not fulfill their obligations, resulting in backers facing great losses because of the project or venture failing [20]. As a result, project creators possess information about the project that a backer does not have, such as the true motivations and behavioral intentions of the creator. Therefore, it becomes increasingly difficult for potential backers to ascertain the true meaning of the project before the actual investment because the true intentions and capabilities of the creator are unobservable [37].

\subsection{Problems of Information Asymmetry in Crowdfunding}

The problem of asymmetric information becomes increasingly severe in the context of crowdfunding, which raises two main issues. First, before evaluating the actual quality of the project on crowdfunding platforms, investment decisions are made by the potential backers once the campaign has ended, whereas transactions on diverse platforms such as eBay are more chronological and a rating is given after each transaction by the user within a short period. Such a platform allows buyers to review the remarks of their predecessors based on the specifics of a product or a service [38]. Such a rating system enhances the reputation among the market participants by sharing their experience with other users about any specific product or service. However, such a reputation system might also cause the problem of bias to arise. Thus, a reputation mechanism on crowdfunding platforms is rare, and it has become difficult for potential backers to differentiate between high and low quality projects due to the biased nature of the information provided by the founder [39].

Second, a high-level of information asymmetry coming from the project creator through overstating the quality of his project or by withholding information will encourage fraud on crowdfunding platforms or pass a low-quality project as being a high-quality one. Thus the founder's incompetence and risk associated with the project can be perceived as serious issues [40,41]. Except for equity crowdfunding, more efforts are required to strengthen the rules and regulations of other crowdfunding models in order to attract more backers and raise more funds. On the contrary, the vetting process in the traditional sources of financing, ranging from venture capitalists to angel financers, highlights the importance of quality, legal, and ethical issues in attracting more investors. Such a screening process is not applied by the project creator on a reward-based crowdfunding platform, which increases the failure rate of the projects. As per the statistical information collected from Kickstarter, $9 \%$ of project creators are unable to provide the promised reward to the backers while those who succeed in offering the promised reward are unable to deliver on time [41].

Such problems arise when project creators are inexperienced. What is more, when projects are posted on the crowdfunding platform at the early phases of development, fundamental uncertainties related to the project outcome need to be overcome, and a robust project plan is needed to attract interest [40]. Such problems limit the backers' ability to differentiate between good and bad investments. Consequently, it becomes increasingly difficult for the backers to invest a large amount of money, given their desire to reduce the level of risk arising from uncertainty. These reasons make the platforms less attentive and attractive for the project founders, especially in the case of complex and innovative projects that require more capital [42]. 


\subsection{Possible Determinants of Information Asymmetry on Crowdfunding Platforms}

According to Wessel [39], the three main market participants are the platform provider, project creators, and backers. Information asymmetry is in regards to all the previously mentioned participants.

A platform provider is tasked with solving the problem of information asymmetries as they have more authority to influence the dynamics within the ecosystem of the platform. Between the creator and backer, platform providers act like intermediaries because they make and enforce the governance structure of the platform and develop the ownership, decision rights, and controls inside the platform, in order to employ and bring in stakeholders from other platforms $[43,44]$. One of the critical responsibilities of project providers is ensuring proper screening processes and control mechanisms for all projects submitted to the crowdfunding platform, so as to satisfy the minimum level of quality assurance. This will decrease the investment risks for potential backers [39].

The project creators and backers can solve the problem of information asymmetry through signaling (e.g., Spence [45,46]) and screening (e.g., Stiglitz [47]) without depending on the platform provider, who acts like an intermediary in formulating and regulating the transactions. Signals are the actions taken by an agent, called project creator, to disclose project related information to the principal, called the backer. In crowdfunding, uncertainties of the signaling competence can be mitigated by the project creator through experience or education. Through screening, the project creator first learns as much as possible about the agent and then discloses the most attractive and incentivized information to the potential backers (agent) [42]. Table 1 summarizes the previous studies on crowdfunding that are related to this paper. 
Table 1. Summary of previous studies.

\begin{tabular}{|c|c|c|c|c|c|c|}
\hline Author of the Paper & Focus Area & Research Gap & Theoretical Stance & Paradigm/Method & Sample & Findings \\
\hline Mollick [20] & $\begin{array}{l}\text { Exploring the dynamics of } \\
\text { crowdfunding and how it } \\
\text { operates (drivers of success, } \\
\text { the impact of geography, } \\
\text { post-funding behaviors) }\end{array}$ & $\begin{array}{l}\text { Using a large dataset, an } \\
\text { attempt to avail an } \\
\text { analytical understanding of } \\
\text { the dynamics of } \\
\text { crowdfunding. }\end{array}$ & $\begin{array}{l}\text { The role of key quality signals. } \\
\text { Impact of network size in } \\
\text { providing connections and } \\
\text { endorsing quality. The } \\
\text { influence of geography on } \\
\text { crowdfunding parameters. }\end{array}$ & $\begin{array}{l}\text { Analyze the data } \\
\text { through logistic } \\
\text { regression and used } \\
\text { STATA for distance } \\
\text { information and the } \\
\text { Cox model for delays } \\
\text { in delivery. }\end{array}$ & $\begin{array}{l}\text { A total of } 48,526 \text { projects } \\
\text { for a time period of two } \\
\text { years (2009 to } 07 / 2012) \\
\text { have been extracted from } \\
\text { the crowdfunding platform } \\
\text { called Kickstarter across } \\
\text { all categories. }\end{array}$ & $\begin{array}{l}\text { Project quality (such as the presence of } \\
\text { video, updates and spelling correctness) } \\
\text { and personal networks (Facebook friends) } \\
\text { are positively related to the success of } \\
\text { fundraising. Both project type and } \\
\text { funding success are influenced by } \\
\text { geography. The majority of founders try to } \\
\text { fulfill their promise to funders, but mostly } \\
\text { not in a timely manner, with longer delays } \\
\text { found in larger and overfunded projects }\end{array}$ \\
\hline Courtney et al. [11] & $\begin{array}{l}\text { Examines when signals and } \\
\text { third-party endorsement, } \\
\text { obtained from multiple } \\
\text { sources that improve or } \\
\text { diminish one } \\
\text { another's effect. }\end{array}$ & $\begin{array}{l}\text { Signals through start-up } \\
\text { actions and characteristics } \\
\text { can mitigate information } \\
\text { asymmetry concerns about } \\
\text { project quality and } \\
\text { founder credibility. }\end{array}$ & $\begin{array}{l}\text { Signals originating from the } \\
\text { start-up, endorsement } \\
\text { originating from third parties, } \\
\text { the interplay of signals and } \\
\text { third-party endorsement. }\end{array}$ & $\begin{array}{l}\text { Analyze the data } \\
\text { through logistic } \\
\text { regression, two-stage } \\
\text { Heckman procedure, } \\
\text { and first stage } \\
\text { probit model. }\end{array}$ & $\begin{array}{l}\text { A total of } 170,248 \text { projects } \\
\text { from } 4 / 2009 \text { to } 12 / 2015 \\
\text { were extracted from the } \\
\text { crowdfunding platform } \\
\text { called Kickstarter across } \\
\text { all categories. }\end{array}$ & $\begin{array}{l}\text { Both start-up originating signals and } \\
\text { third-party endorsement mitigate } \\
\text { information asymmetry concerns about } \\
\text { project quality and founder credibility. }\end{array}$ \\
\hline $\begin{array}{l}\text { Crosetto and } \\
\text { Regner [48] }\end{array}$ & $\begin{array}{l}\text { Exploring the dynamics of } \\
\text { funding and pledgers' } \\
\text { motivations. }\end{array}$ & $\begin{array}{l}\text { An attempt to avail an } \\
\text { analytical understanding } \\
\text { about project-level and } \\
\text { pledge-level variables in } \\
\text { crowdfunding. }\end{array}$ & $\begin{array}{l}\text { Crowdfunding and innovation, } \\
\text { empirical studies on } \\
\text { crowdfunding. }\end{array}$ & $\begin{array}{l}\text { Normalized project } \\
\text { time, descriptive } \\
\text { statistics, linear } \\
\text { regression, } \\
\text { questionnaire, and } \\
\text { interviews. }\end{array}$ & $\begin{array}{l}\text { A total of } 2254 \text { projects } \\
\text { extracted from German } \\
\text { platform called Startnext } \\
\text { from } 10 / 2010 \text { to } 2 / 2014 .\end{array}$ & $\begin{array}{l}\text { Majority of the projects that eventually } \\
\text { succeed are not on a successful track at } \\
75 \% \text { of their funding period. And late } \\
\text { successes are basically boosted by an } \\
\text { information cascade during the final } 25 \% \\
\text { of the funding duration. Results from } \\
\text { interviews and questionnaires prove that } \\
\text { project communication efforts play a role } \\
\text { in making a project successful. }\end{array}$ \\
\hline Colombo et al. [49] & $\begin{array}{l}\text { Why early contributions } \\
\text { are so necessary for } \\
\text { crowdfunding success? } \\
\text { What are the core factors } \\
\text { that attract early } \\
\text { contributions? }\end{array}$ & $\begin{array}{l}\text { Investigating the } \\
\text { relationship between early } \\
\text { support (in forms of capital } \\
\text { and backers) and final } \\
\text { success. Furthermore, } \\
\text { examining the role of social } \\
\text { capital in crowdfunding via } \\
\text { fascinating early } \\
\text { contributions. }\end{array}$ & $\begin{array}{l}\text { Uncertainties and information } \\
\text { asymmetries at the initial stage } \\
\text { of crowdfunding. The role of } \\
\text { early contributions and } \\
\text { internal social capital in } \\
\text { attracting initial funding. }\end{array}$ & $\begin{array}{l}\text { Analyze the data } \\
\text { through the Probit } \\
\text { and Tobit model. }\end{array}$ & $\begin{array}{l}\text { Extracted a total of } 669 \\
\text { projects in four categories, } \\
\text { namely design, technology, } \\
\text { film, and video and also } \\
\text { video games from } \\
\text { Kickstarter, covering the } \\
\text { time period from } 10 / 2012 \\
\text { to } 01 / 2013 \text {. }\end{array}$ & $\begin{array}{l}\text { Concluded that internal social capital is } \\
\text { critical in raising funds and engaging } \\
\text { funders in the initial phase of } \\
\text { crowdfunding of a project. It is reported } \\
\text { that there is a positive relationship } \\
\text { between early contributions and } \\
\text { probability of final success hence, they } \\
\text { mediate the influence of internal social } \\
\text { capital on project success. }\end{array}$ \\
\hline Polzin et al. [50] & $\begin{array}{l}\text { How does the type of } \\
\text { information used by } \\
\text { crowdfunders vary with } \\
\text { the strength of their ties to } \\
\text { the project? }\end{array}$ & $\begin{array}{l}\text { Empirically tested the } \\
\text { heterogeneity between } \\
\text { in-crowd and out-crowd } \\
\text { funders by analyzing large } \\
\text { scale data through a survey } \\
\text { among project funders. }\end{array}$ & $\begin{array}{l}\text { Signaling in early-stage finance } \\
\text { and information cascades, } \\
\text { in-crowd information needs } \\
\text { and out-crowd } \\
\text { information need. }\end{array}$ & $\begin{array}{l}\text { Descriptive Statistics, } \\
\text { factor analysis and } \\
\text { logistic regression. }\end{array}$ & $\begin{array}{l}\text { A total of } 283 \text { observations } \\
\text { assessed through 5-point } \\
\text { Likert scale questionnaire. }\end{array}$ & $\begin{array}{l}\text { Concluded that in-ward investors rely } \\
\text { more on information about the project } \\
\text { creator than out-crowd investors. } \\
\text { Out-crowd investors do not give more } \\
\text { importance to the information about the } \\
\text { project itself than in-crowd investors. }\end{array}$ \\
\hline
\end{tabular}


Table 1. Cont

\begin{tabular}{|c|c|c|c|c|c|c|}
\hline Author of the Paper & Focus Area & Research Gap & Theoretical Stance & Paradigm/Method & Sample & Findings \\
\hline Ahlers et al. [17] & $\begin{array}{l}\text { How do venture quality } \\
\text { (human, social, and } \\
\text { intellectual capital) and } \\
\text { uncertainty level (equity } \\
\text { share, financial projections) } \\
\text { impact } \\
\text { crowdfunding success? }\end{array}$ & $\begin{array}{l}\text { Empirically examine the } \\
\text { impact of signals used by } \\
\text { entrepreneurs to motivate } \\
\text { investors, and to contribute } \\
\text { an equity-based } \\
\text { crowdfunding project. }\end{array}$ & $\begin{array}{l}\text { Information asymmetries in } \\
\text { crowdfunding. Signaling } \\
\text { values of venture quality } \\
\text { attributes and indicators of } \\
\text { uncertainty that impact on the } \\
\text { probability of success. }\end{array}$ & $\begin{array}{l}\text { Analyze the data } \\
\text { through Univariate } \\
\text { analysis, binomial } \\
\text { regression, Ordinary } \\
\text { Least Square (OLS) } \\
\text { regression, and } \\
\text { exponential } \\
\text { hazard models. }\end{array}$ & $\begin{array}{l}\text { A total of } 104 \text { campaigns } \\
\text { published on ASSOB from } \\
10 / 2006 \text { to } 10 / 2011 .\end{array}$ & $\begin{array}{l}\text { Regarding venture quality signals, human } \\
\text { capital is positively related to funding } \\
\text { success; whereas less evidence available in } \\
\text { supporting the role of social capital and } \\
\text { intellectual capital. Retaining equity and } \\
\text { providing detailed financial forecasts can } \\
\text { act as effective signals to decrease } \\
\text { information asymmetry and therefore } \\
\text { increase the likelihood of success. }\end{array}$ \\
\hline Bi et al. [23] & $\begin{array}{l}\text { What is the impact of } \\
\text { online information on } \\
\text { investing decisions in } \\
\text { reward-based } \\
\text { crowdfunding? }\end{array}$ & $\begin{array}{l}\text { Introducing the elaboration } \\
\text { likelihood model to } \\
\text { crowdfunding literature } \\
\text { and investigating which } \\
\text { type of online information } \\
\text { has a resilient impact on } \\
\text { investment behavior. }\end{array}$ & $\begin{array}{l}\text { Elaboration likelihood model: } \\
\text { central route (project quality } \\
\text { signals) and peripheral route } \\
\text { (electronic word-of-mouth). } \\
\text { Which route, and information } \\
\text { can influence the decision } \\
\text { to invest? }\end{array}$ & $\begin{array}{l}\text { Hierarchical multiple } \\
\text { regression for the full } \\
\text { sample and for each } \\
\text { project category. }\end{array}$ & $\begin{array}{l}\text { A total of } 999 \text { projects } \\
\text { extracted from a Chinese } \\
\text { platform called } \\
\text { zhongchou.com in the } \\
\text { categories of Science \& } \\
\text { Technology, Art, } \\
\text { Entertainment, and } \\
\text { Agriculture. }\end{array}$ & $\begin{array}{l}\text { Explanatory description of texts and } \\
\text { higher video counts higher project quality } \\
\text { signals; more "Like" and reviews suggest } \\
\text { better electronic word-of-mouth. } \\
\text { Generally, the effects of the central route } \\
\text { and peripheral factors on investors' } \\
\text { funding decisions are almost equal. }\end{array}$ \\
\hline Oba et al. [8] & $\begin{array}{l}\text { If a project is successful, } \\
\text { then it creates a value } \\
\text { proposition and signals it } \\
\text { effectively. }\end{array}$ & $\begin{array}{l}\text { Analyze the platform } \\
\text { reputation, reward } \\
\text { attributed and } \\
\text { characteristics of } \\
\text { project owner. }\end{array}$ & $\begin{array}{l}\text { Signaling theory and } \\
\text { information asymmetry, } \\
\text { ecosystem of crowdfunding } \\
\text { in Turkey. }\end{array}$ & $\begin{array}{c}\text { Descriptive statistics, } \\
\text { univariate analysis } \\
\text { ( } t \text {-test), ANOVA, } \\
\text { regression analysis. }\end{array}$ & $\begin{array}{l}\text { A total of } 354 \text { campaigns } \\
\text { extracted from three } \\
\text { Turkish crowdfunding } \\
\text { platforms e.g., Fongogo, } \\
\text { Fonlabeni and crowdFON. }\end{array}$ & $\begin{array}{l}\text { They concluded that platform reputation } \\
\text { and entrepreneurial capacity of the project } \\
\text { owner are strongly associated with } \\
\text { success of the project. }\end{array}$ \\
\hline $\begin{array}{l}\text { Gangi and } \\
\text { Daniele [32] }\end{array}$ & $\begin{array}{l}\text { How early-late backers and } \\
\text { mentors affect } \\
\text { reward-based } \\
\text { crowdfunding campaigns. }\end{array}$ & $\begin{array}{l}\text { Resolving the information } \\
\text { asymmetry barriers among } \\
\text { insiders and outsiders in } \\
\text { determining the campaign } \\
\text { success. }\end{array}$ & $\begin{array}{l}\text { Impact of early-late backers. } \\
\text { Impact of project mentor. }\end{array}$ & $\begin{array}{l}\text { Descriptive statistics } \\
\text { and multivariate } \\
\text { analysis. }\end{array}$ & $\begin{array}{l}\text { A total of } 578 \text { campaigns } \\
\text { extracted from two Italian } \\
\text { platforms e.g., Produzioni } \\
\text { dal basso and Eppala. }\end{array}$ & $\begin{array}{l}\text { They concluded that both type of funders } \\
\text { are remarkably important for the } \\
\text { project success. }\end{array}$ \\
\hline
\end{tabular}




\section{Research Hypotheses}

\subsection{Role of Media}

Entrepreneurial actions in crowdfunding campaigns in the shape of project quality and founder's credibility largely facilitate the process of attracting potential backers and increase the success rate of crowdfunding. One prominent action that could be taken by start-ups is the use of media channels in crowdfunding projects, such as video and images. Video and images develop the backers understanding of the project regarding a product's attributes and the stages of development of a project. Through such information, backers can easily ascertain the quality of the project by evaluating the product feasibility as well as market readiness [20]. Thus, the role of media boosts backers' trust concerning the creator's ability to deliver the product on time and live up to the expectations. Furthermore, the use of media can demonstrate the founder's credibility, preparedness, and signals the project's quality $[11,51]$.

Albeit, many project creators imitate video and images from high-quality projects for the sake of bearing less expenses. Even so, such monetary expenses for making the video and images are marginal due to the advancement of information technology (e.g., use of smartphones), demonstrating the preparedness of the project by the creators, by reflecting the efforts and ability of the founder in making the project more developed and displaying their working model in the shape of video and images. Therefore, it becomes vital to adopt video and images for making the project more significant and appealing [51]. We, therefore, hypothesize:

Hypothesis 1 (H1). The media presentation impacts positively on crowdfunding projects which leads to the success of crowdfunding campaigns.

\subsection{Founder's Past Experience}

External investors consider the start-up's human capital before deciding to invest or finance the project $[52,53]$. More precisely, a founder's experience and his team's skills can facilitate the investors in making funding decisions $[54,55]$. The level of experience of each founder varies, and some of them successfully gather more funding through crowdfunding campaigns than others. Such experience predicts the founder's product quality and his credibility. Potential backers evaluate the quality of the current project through a founder's past experience (or success). In addition, more successful projects launched and managed by the founder represent a certain guarantee for developing and delivering the current projects [11].

It is difficult for the founders to mislead the potential backers concerning whether they have failed projects because most of the renowned crowdfunding platforms such as Indigogo, Kickstarter, Crowdfunder, Crowd-cube, etc., keep the founder's prior projects recorded. Similarly, their successes are also recorded. Such records are easily accessible to the backers and cannot be manipulated. Hence, the founder's past successful records associated with the current project quality and founder's level of credibility can be helpful in differentiating high-from low-quality projects. We, therefore, hypothesize:

Hypothesis 2 (H2). The founder's past successful projects have a positive impact upon the likelihood of a successful crowdfunding campaign.

Figure 1 presents a graphical representation of the research model. 


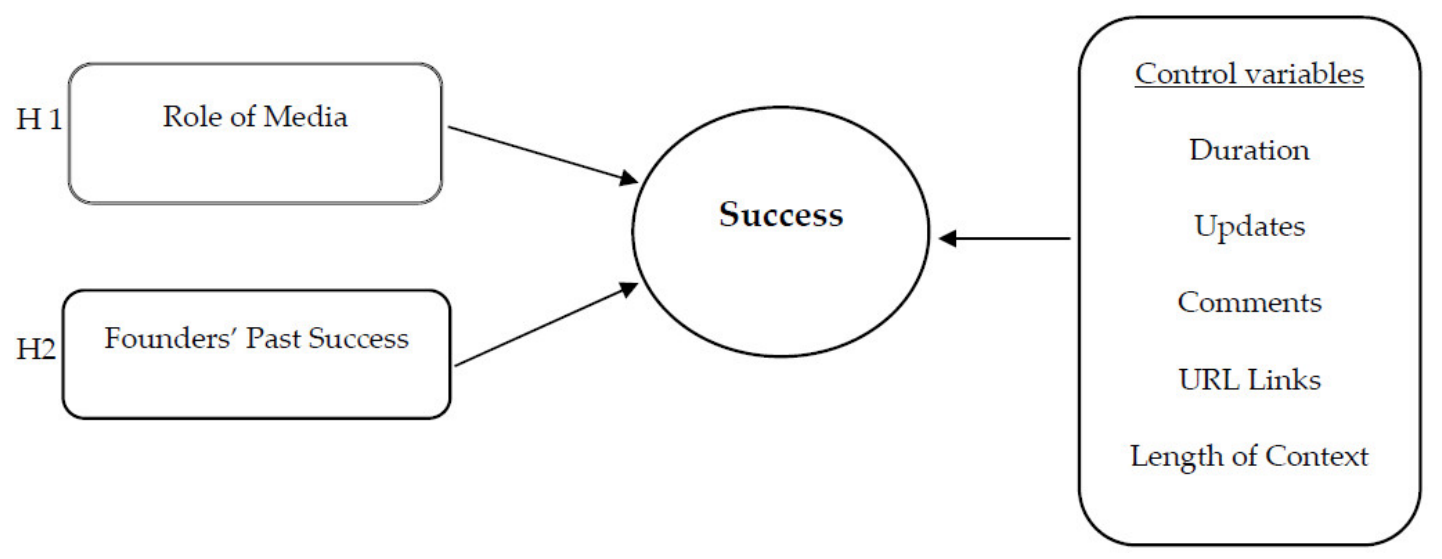

Figure 1. Taxonomy of the research model.

\section{Data and Methods}

\subsection{Context Construction and Data Sample}

We collected data from a UK-based lending platform called Crowdfunder.co.uk, which is the largest and No. 1 ranked reward-based crowdfunding platform in the UK [56]. Since its inception in 2012, the platform has facilitated crowd funders from around the globe by raising $£ 50$ million ( $\$ 67$ million) in pledged capital, but the team is expecting to increase to a total value of $£ 200$ million by 2020. Currently, they have 600,000 members, but they are expecting 2 million members by $2020[57,58]$. Due to the generalist approach, Crowdfunder became famous among the community by hosting projects from diverse categories such as arts, business, charities, community, community shares, environment, film and theatre, food and drink, heritage, music, politics, publishing, schools, social enterprise, sports, technology, and university.

We have selected the United Kingdom and Crowdfunder-based sample for several reasons. First, the British economy is an archetypal moderate open Western economy in comparison to the US. The UK is part of EEA (European Economic Area) and holds a similar ratio of internet users as many other Western countries such as Germany or the US. Hence, the findings from the British sample can give predictions and indications regarding how reward-based crowdfunding can mitigate the problem of information asymmetry which will lead the founders to attain success and attract more backers towards their campaign. Second, Crowdfunder makes a tempting research target due to its strong market position and strong market orientation. It would be appealing to attain future research opportunities by using Crowdfunder data because of its international expansion and regulatory approval to do so. Third, keeping in view the potential future research, British data offers research opportunities that engage the use of personal information that can be obtained, anonymously, from diverse government organizations. Such data is normally restricted for use in most Western countries, such as the US, due to tight privacy regulations.

Crowdfunder has adopted an all or nothing (hereafter AON) business strategy, meaning no funds will be given to the project founders until the target amount is met. However, the campaign on the platform will be active until their deadline. In this case, the campaign could raise more than $100 \%$ of the expected amount [58]. Considering data from a platform that adopted the AON business strategy is suitable for our objective because it allows us to construct clear measures for crowdfunding success.

We observed all the campaigns launched by founders on Crowdfunder from January 2012 to November 2017, excluding: the campaigns launched outside the UK, the crowdfunding goals less than $£ 1000$, projects being cancelled by the founder before the funding round, projects suspended by Crowdfunder, and projects that are still active during the data collection period. The final dataset contains 14,887 projects backed by 497,285 backers with 37,877 comments posted by backers on all the projects. A total of $4786(32.14 \%)$ projects were successful in reaching the funding goal and have raised a cumulative total of over $£ 26$ million GBP. 


\subsection{Measures}

\subsubsection{Dependent Variables}

\section{Success Flag}

The dependent variable hereafter (DV) refers to the venture success in attracting more financial resources from the backers. We use three different DV proxies for the success measures: fully funded, the number of backers, and funding amount. These estimated indicators have been used in prior research work $[17,20,49,59-61]$. The fully funded dichotomous variable $(0 / 1)$ specifies whether the target amount is being received by the project. We adopted this success variable to evaluate whether projects that received full funding differ significantly from projects that did not. Number of backers counts the number of outside backers who backed the project (excluding founders). Funding amount indicates the overall amount generated by the project in millions of British Pounds.

\subsubsection{Independent Variables}

\section{Media}

We crafted an ordinal measure of media usage which is based on the richness of the media employed in the project. Usage of media brings peculiar features related to project which enhances the richness of the media in online communication $[62,63]$. Four basic codes allocated to media have been used: zero, one, two, and three. If a project possesses no video and no image, the value is equal to zero, one if it has only an image, two, if it has only a video, three if it has both video and images. According to Rockmann and Northcraft [64], using video in the project enriches the project more than images and text. Such usage enhances the level of trust by the recipients. Most of the platforms strongly recommend the project creators to use visual media formats to make the project's description more accurate and attractive.

\section{Founder's Past Success}

The second independent variable is past success which is the natural logarithm of one plus the number of previous successful projects completed by the project founder on the Crowdfunder platform before starting the current project. This will identify the founder's past success and capability that he/she has delivered the rewards to the backers on time in exchange for the capital provided.

\subsubsection{Control Variables}

The following are the control variables that we believe may strongly influence the crowdfunding success.

Duration: the number of days through which a project is available and accepts funding. Length of the Context: identifies the overall attributes of the project, explained by the founder in the project description. A more comprehensive explanation will alleviate the asymmetric information problem and greatly enhance the preparedness and quality of the project. We code this variable in the form of counting the number of words used in the project description; the more it explains, the better the understanding of the backers with the project. Updates: is a dummy variable codedif the project founder posts regular updates within the first week of project initiation. Comments: potential funders mostly express their thoughts in the form of comments about the project, either pleasure or displeasure. We code a log of one plus the number of comments left by the backers during an active campaign. Most of the founders provide additional information about the project in the form of text, images or video by sharing an external link. ULR Link: is a log of one plus the number of external URL links shared by the founder in the project description. 


\subsection{Methods}

Given the sample size of this research, we analyzed the data by performing logistic and Tobit estimations. Anderson et al. [65] argued that logistic models are used for discrete outcome modelling for binary outcomes ( 0 and 1 ) or for three or more outcomes (multinomial logit). The logit model operates under the logit distribution and is preferred for large sample sizes. Therefore, logistic based models have been applied to several crowdfunding research topics $[11,20,32,66,67]$. In the current study, we examined the success of a project through a dichotomous variable (i.e., fully funded). Accordingly, a binary behavior model was applied. On the other hand, according to Smith and Brame [68], a Tobit estimation is a form of linear regression. If a continuous dependent variable needs to be regressed, the Tobit model allows regression of such a variable while censoring it so that the regression of a continuous dependent variable can happen. It allows the analyst to specify a lower (or upper) threshold to censor the regression. Previously, the Tobit estimations have been applied in crowdfunding research topics $[67,69,70]$. We examined the success of a project through the number of backers and funding amount using the Tobit estimation censored at 0 to analyze the results of estimations as reported in Table 4.

We used the logarithmic transformations of the dependent and independent scale variables because Log transformation diminishes the variables' skewness, heteroscedasticity, and enhances the appropriateness of the results in the models [71-73]. Table 4 shows the Models (e.g., I, II, III) related to the aggregate measures of the role of media and founders' past success. We estimate the following equation.

$$
\text { fundraising success }=\alpha_{0}+\beta_{1} \text { role of media }+\beta_{2} \text { founders' past success }+ \text { controls }+\varepsilon
$$

where fundraising success is the amount of funds pledged (British pounds), the number of backers, and the goal attainment. The predictor variables, role of media, and founders' past success as well as controls.

\section{Empirical Results}

\subsection{Multicollinearity Analysis}

To measure the multicollinearity diagnostic, we examined the estimated variance inflation factor (VIF) and tolerance values by using the regression module of IBM SPSS Statistics 23 . We concluded that a single individual VIF score was below three, whereas, the tolerance values ranged from 0.6 to 0.9 . According to Hair et al. [74] and Liu et al. [75], the VIF values were far below the suggested value of 10 . The VIF and tolerance values of this study were also within the criteria (VIF $<5$ and Tolerance $>0.2)$ indicating that the multicollinearity of the measures was not likely to be a concern.

\subsection{Descriptive Statistics}

Table 2 shows the descriptive statistics of the variables used in our analysis. A total 14,887 campaigns were considered for the analysis. Thirty-two percent of the projects were successful in achieving their target fund, whereas $68 \%$ of campaigns were unsuccessful. Such a large difference in percentage exists due to cynical arguments such as: since Crowdfunder delivers the funding amount on an AON basis; and secondly, Crowdfunder makes self-funding difficult because individuals cannot use the same name, credit card or address for pledge as they did at the time of setting up their project. On average, each campaign had a funding goal of $£ 1782.24$ from an average of 33 backers. Eighty-four percent of campaigns included videos and images in the description of their project presentation. Twenty-five percent of projects had founders with past success. The founders updated $89 \%$ of projects after launching their project. 
Table 2. Descriptive statistics for metric and binary variables.

\begin{tabular}{ccccc}
\hline Variables & Mean & Min & Max & Standard Deviation \\
\hline Fully funded & 0.32 & 0 & 1.00 & 0.46 \\
No. of backers & 33.40 & 0 & 4913.00 & 118.98 \\
Funding amount & $£ 1782.24$ & 1 & $367,200.00$ & 8356.76 \\
Role of media & 0.84 & 0 & 3.00 & 1.07 \\
Founder's past success & 0.25 & 0 & 1.96 & 0.18 \\
Duration (days) & 37.85 & 0 & 1000.00 & 19.20 \\
Length of the context & 2238.97 & 0 & $24,506.00$ & 2.46 .32 \\
Updates & 0.89 & 0 & 41.00 & 0.39 \\
Comments & 0.26 & 0 & 2.50 & 0.27 \\
URL links & 0.15 & 0 & 1.86 & \\
\hline
\end{tabular}

\subsection{Correlation Matrix}

Table 3 presents the results of the correlation coefficients between variables. The pairwise correlation coefficients between all the variables are relatively low but statistically significant at $1 \%$ and $5 \%$, respectively.

\subsection{Multivariate Analysis}

By specifying our model, we tested our hypothesis as described in Table 4 for the three proxies of the DVs, the natural log of a number of backers, natural log of funding amount, and whether the target amount has been successfully achieved by the campaign (fully funded). In Table 4, model I indicates the estimates for a number of backers, while Model II indicates the estimates for the funding amount, and model III indicates the estimates for goal attainment (fully funded).

Our results related to the control variables are consistent with past work in the crowdfunding setting. Only the duration is negative but significant in all three models. Updates, comments, and URL links are found to be positively and significantly related to all three models (Table 4). It is intuitive to say that response to comments, quick updates, and providing extra web links about the projects increase the chances of success for a given campaign.

In Models I and II, the DVs are defined as the number of backers and funding amount. All independent variables included in the models are found to have a significant effect on the number of backers and funding amount. In both models, the coefficients of the Tobit estimations for the role of media and founder's past success are statistically significant at $1 \%$. The score of chi square test for both the DVs are significant at $p<0.001$.

The analysis in Model III revealed that these independent variables (role of media and founders past success) could explain $26 \%\left(R^{2}\right.$ for Model III $\left.=0.26\right)$ of the project achieved their target amount. It is rational to find that these two independent variables are indicators of success. Since, Crowdfunder operates on an AON basis, reaching the targeted amount of funds is an important consideration for project founder. The founder could improve media presentation as well as information related to past success to mitigate not only the asymmetric issues but also motivate the backers to fund the project. Furthermore, the score of chi-square was significant at $p<0.001$. 
Table 3. Correlation Matrix.

\begin{tabular}{|c|c|c|c|c|c|c|c|c|c|c|}
\hline Variables & (1) & (2) & (3) & (4) & (5) & (6) & (7) & (8) & (9) & (10) \\
\hline Fully Funded (1) & 1 & & & & & & & & & \\
\hline No. of Backers (2) & $\begin{array}{l}0.218^{* *} \\
(0.000)\end{array}$ & 1 & & & & & & & & \\
\hline Funding Amount (3) & $\begin{array}{l}0.180^{* *} \\
(0.000)\end{array}$ & $\begin{array}{l}0.572 \text { ** } \\
(0.000)\end{array}$ & 1 & & & & & & & \\
\hline Role of Media (4) & $\begin{array}{l}0.174^{* *} \\
(0.000)\end{array}$ & $\begin{array}{l}0.117^{* * *} \\
(0.000)\end{array}$ & $\begin{array}{l}0.146^{* *} \\
(0.000)\end{array}$ & 1 & & & & & & \\
\hline $\begin{array}{c}\text { Founder's Past } \\
\text { Success (5) }\end{array}$ & $\begin{array}{l}0.112 * * \\
(0.000)\end{array}$ & $\begin{array}{l}0.026^{* *} \\
(0.001)\end{array}$ & $\begin{array}{c}0.013 \\
(0.120)\end{array}$ & $\begin{array}{l}0.064^{* *} \\
(0.000)\end{array}$ & 1 & & & & & \\
\hline Duration (6) & $\begin{array}{c}-0.152 \text { ** } \\
(0.000)\end{array}$ & $\begin{array}{l}-0.007 \\
(0.422)\end{array}$ & $\begin{array}{l}0.021 * \\
(0.010)\end{array}$ & $\begin{array}{l}0.087^{* *} \\
(0.000)\end{array}$ & $\begin{array}{c}-0.019 * \\
(0.022)\end{array}$ & 1 & & & & \\
\hline Updates (7) & $\begin{array}{l}0.242 * * \\
(0.000)\end{array}$ & $\begin{array}{l}0.313^{* *} \\
(0.000)\end{array}$ & $\begin{array}{l}0.281 * * \\
(0.000)\end{array}$ & $\begin{array}{l}0.238 \text { ** } \\
(0.000)\end{array}$ & $\begin{array}{l}0.020 * \\
(0.013)\end{array}$ & $\begin{array}{l}0.053^{* *} \\
(0.000)\end{array}$ & 1 & & & \\
\hline Comments (8) & $\begin{array}{l}0.369 * * \\
(0.000)\end{array}$ & $\begin{array}{l}0.379 * * \\
(0.000)\end{array}$ & $\begin{array}{l}0.299 * * \\
(0.000)\end{array}$ & $\begin{array}{l}0.184^{* *} \\
(0.000)\end{array}$ & $\begin{array}{l}0.162 * * \\
(0.000)\end{array}$ & $\begin{array}{c}-0.057^{* *} \\
(0.000)\end{array}$ & $\begin{array}{l}0.294^{* *} \\
(0.000)\end{array}$ & 1 & & \\
\hline URL Links (9) & $\begin{array}{l}0.174^{* *} \\
(0.000)\end{array}$ & $\begin{array}{l}0.152 * * \\
(0.000)\end{array}$ & $\begin{array}{l}0.158 * * \\
(0.000)\end{array}$ & $\begin{array}{l}0.329 * * \\
(0.000)\end{array}$ & $\begin{array}{l}0.062 * * \\
(0.000)\end{array}$ & $\begin{array}{l}0.023 \text { ** } \\
(0.004)\end{array}$ & $\begin{array}{l}0.217^{* *} \\
(0.000)\end{array}$ & $\begin{array}{l}0.153 * * \\
(0.000)\end{array}$ & 1 & \\
\hline $\begin{array}{l}\text { Length of the } \\
\text { Context (10) }\end{array}$ & $\begin{array}{l}0.165^{* *} \\
(0.000)\end{array}$ & $\begin{array}{l}0.202^{* *} \\
(0.000)\end{array}$ & $\begin{array}{l}0.233 \text { ** } \\
(0.000)\end{array}$ & $\begin{array}{l}0.399 * * \\
(0.000)\end{array}$ & $\begin{array}{l}0.022 \text { ** } \\
(0.008)\end{array}$ & $\begin{array}{l}0.088^{* *} \\
(0.000)\end{array}$ & $\begin{array}{l}0.337^{* *} \\
(0.000)\end{array}$ & $\begin{array}{l}0.245^{* *} \\
(0.000)\end{array}$ & $\begin{array}{l}0.439^{* *} \\
(0.000)\end{array}$ & 1 \\
\hline
\end{tabular}

Notes: This table describes the Pearson correlations coefficients for the metric and binary variables in Table $3 .{ }^{* *}$ and ${ }^{*}$ indicates statistical significance at the $1 \%$ and $5 \%$ levels, respectively. 
Table 4. Impact of media and founders' past success on fundraising success.

\begin{tabular}{|c|c|c|c|}
\hline \multirow{4}{*}{$\begin{array}{c}\text { DV } \\
\text { Method }\end{array}$} & I & II & III \\
\hline & Number of Backers & Funding Amount & Fully Funded \\
\hline & Tobit & Tobit & Logistic reg. \\
\hline & B(SE) & $\mathrm{B}(\mathrm{SE})$ & $\mathrm{B}(\mathrm{SE})$ \\
\hline Role of media & $\begin{array}{c}0.076^{* * *} \\
(0.012)\end{array}$ & $\begin{array}{c}0.068^{* * *} \\
(0.011)\end{array}$ & $\begin{array}{c}0.129^{* * * *} \\
(0.020)\end{array}$ \\
\hline Founders' past success & $\begin{array}{c}0.457^{* * *} \\
(0.064)\end{array}$ & $\begin{array}{c}0.282 * * * \\
(0.061)\end{array}$ & $\begin{array}{c}0.771^{* * *} \\
(0.109)\end{array}$ \\
\hline Duration & $\begin{array}{c}-1.101^{* * *} \\
(0.052)\end{array}$ & $\begin{array}{c}-0.832^{* * * *} \\
(0.049)\end{array}$ & $\begin{array}{c}-1.854^{* * *} \\
(0.091)\end{array}$ \\
\hline Updates & $\begin{array}{c}0.888^{* * *} \\
(0.045)\end{array}$ & $\begin{array}{c}0.891^{* * *} \\
(0.040)\end{array}$ & $\begin{array}{c}1.533^{* * *} \\
(0.076)\end{array}$ \\
\hline Comments & $\begin{array}{c}0.983^{* * *} \\
(0.032)\end{array}$ & $\begin{array}{c}0.940 * * * \\
(0.028)\end{array}$ & $\begin{array}{c}1.637^{* * *} \\
(0.054)\end{array}$ \\
\hline URL Links & $\begin{array}{c}0.393^{* * * *} \\
(0.046)\end{array}$ & $\begin{array}{c}0.381^{* * * *} \\
(0.042)\end{array}$ & $\begin{array}{c}0.602^{* * * *} \\
(0.077)\end{array}$ \\
\hline Length of context & $\begin{array}{c}0.060 \\
(0.035)\end{array}$ & $\begin{array}{l}0.103^{* *} \\
(0.034)\end{array}$ & $\begin{array}{l}0.123 \text { * } \\
(0.061)\end{array}$ \\
\hline Constant & $\begin{array}{l}0.358 \text { * } \\
(0.126)\end{array}$ & $\begin{array}{c}-0.259 \text { * } \\
(0.121)\end{array}$ & $\begin{array}{l}0.562 \text { ** } \\
(0.217)\end{array}$ \\
\hline Sigma & $0.404^{* * *}$ & $1.172 * * *$ & \\
\hline Observations & 14,887 & 14,887 & 14,887 \\
\hline Uncensored & 10,101 & 10,102 & \\
\hline Left-censored & 4786 & 4785 & \\
\hline Mean VIF & 1.891 & 3.358 & \\
\hline Maximum VIF & 3.267 & 3.928 & \\
\hline Likelihood Chi 2 & 9445 & 7,944 & \\
\hline McFadden's pseudo $\mathrm{R}^{2}$ & & & 0.170 \\
\hline Nagelkerke pseudo $\mathrm{R}^{2}$ & & & 0.269 \\
\hline
\end{tabular}

Note: ${ }^{* * *} p<0.001,{ }^{* *} p<0.01,{ }^{*} p<0.05$. In parentheses standard errors are reported. (B) stands for Coefficient and (SE) stands for standard error.

Our directional hypothesis predicts that the role of media and founders' past success would be an important predictor of fundraising success. Hypothesis $\mathrm{H} 1$ predicts that the media presentation impacts positively on crowdfunding projects and can lead towards attaining success in crowdfunding campaigns. Such a hypothesis is tested for Model I ( $\beta_{1}=0.76$ at $\left.p<0.001\right)$, Model II $\left(\beta_{1}=0.068\right.$ at $p<0.001)$, and Model III $\left(\beta_{1}=0.129\right.$ at $\left.p<0.001\right)$ in Table 4 . In each case, the role of media was statistically significant $(p<0.001)$ having positive coefficients in respect to measuring crowdfunding success. Therefore, the results provide support for hypothesis H1. Furthermore, the probability of campaign success increases by including the value of media either in the form of image and video.

Hypothesis $\mathrm{H} 2$ predicts that founder's past successful projects positively impact the likelihood of attaining success in crowdfunding campaigns. This hypothesis is tested for Model I (i.e., $\beta_{2}=0.457$ at $p<0.001$ ), Model II (i.e., $\beta_{2}=0.282$ at $p<0.001$ ), and Model III (i.e., $\beta_{2}=0.771$ at $p<0.001$ ). In Table 4, we find that founders' past success has a positive coefficient for all three models and is statistically significant $(p<0.001)$ for all the respective models. Consequently, we confirm hypothesis $\mathrm{H} 2$ as our findings support the proposition that founders' past success is positively associated with the campaign success.

\subsection{Discussion and Contributions}

To answer the research question, this paper addresses the reward-based and AON crowdfunding model. Scholars have contended that in crowdfunding, information asymmetry is pervasive $[11,76]$ between the project founder and backer. Moreover, the backer's decision about pledging in any project 
depends on the true signals given by the project founder related to the product/service offered and about themselves. In such a situation, signals that highlight the qualitative attributes of the product [8] and entrepreneurial experience related to former projects are influential in shaping the decision of potential backer [25].

In the current paper, we examined two manifestations of signaling theory, namely the role of media, and founders past success, and how these multiple signals mitigate the problem of information asymmetry, which enhances the likelihood of success in a crowdfunding campaign. Past studies have discussed the issue in relation to the project and founder's quality (e.g., [11,77]), the role of platform, project, and project owners [8], and role of early-late backers, and the mentor effect [32]. We developed a two-level independent variable model to explain the supporting decision of a potential backer for a particular project.

Previous studies in regards to project quality have focused on preparedness, spelling error, updates, network size, use of visual pitch [20,33], signaling and third party endorsement [11], and the influence of the media richness [64]. Referring to our findings, the success rate is positively significant with the role of media which means if a project is presented using meaningful videos and images, then the project has higher chances of success. According to Mollick and Nanda [78], more transparency in the project pitch in the shape of videos and images helps build a trustful connection between the founder and backer. Therefore, our results demonstrate that the role of media has a significant role in the backers' decision to support a project.

Concerning the information about founder's past success, the statistical results reveal that the success rate is positively significant with founder's past success. According to Courtney et al. [11], information about the project founder during a campaign indicates a level of trust and credibility, which in turn will increase the success rate of the project. Ngoc [25] suggests that indicators of founder quality strongly mitigate the problem of information asymmetry but such results are not valid for reward-based crowdfunding due to the low-risk nature, and also because the product is the sole motive in reward-based crowdfunding. Our results confirm that information related to the founder's past success is strongly associated with a higher probability of success in reward-based crowdfunding.

\subsection{Robustness Tests}

To check the validity and predictive accuracy of our model, we used k-fold cross-validation, and bootstrapping techniques. As we know, logistic regression is less vulnerable than discriminant analysis in the issue of overfitting. Therefore, validation plays an important role when the data sample is relatively small [74].

In the first step, we validate our model through a k-fold cross-validation technique previously used by [25,79-82]. More precisely, an overall dataset is randomly divided into four parts with subsamples from 1 to 3 having 3722 projects and four subsamples having 3721 projects. To fit the model, the first subsample is used as the validation dataset whereas the remaining three subsamples are used as the training dataset.

Now we can calculate the value of DVs for each project by applying the estimated model to the data of the first subsample. It explains that a predicted logit value of success is calculated for each of the observations from the model which previously was not made from that observation. Now we can construct and calculate the area of Receiver Operating Characteristic curve, hereafter (ROC), based on the predicted and actual value of the fully funded (a dichotomous variable). The ROC curve is frequently used to assess and exemplify the binary classifier's goodness-of-fit graphically by plotting sensitivity (positive or negative rate and (1-Specificity)) at different cut-off points for logistic regression. The area under the ROC curve, hereafter (AUC), is used to measure the model classification accuracy, and it ranges from 0.5 to 1.0. A value between these two ranges indicates better goodness-of-fit about the model.

Further, we can repeat the above process three more times so that each of the subsamples becomes the validation data exactly once. The single measure of predictive accuracy can be calculated by taking 
the average of the AUC values from the folds. In Table 5, the AUC values for all the four subsamples are above 0.6 , averaging 0.65 . Also, the true area under the ROC curve is somewhat different from 0.5 $(p<0.05)$, which means that the logistic regression model truly forecasts the success and failure more accurately. Figures 2 and 3 are the ROC curves shown in the following.

Table 5. K-fold cross-validation.

\begin{tabular}{ccccc}
\hline \multicolumn{5}{c}{ Validation Dataset } \\
\hline & Subsample 1 & Subsample 2 & Subsample 3 & Subsample 4 \\
\hline AUC & 0.646 & 0.672 & 0.655 & 0.662 \\
SE ${ }^{\text {a }}$ & 0.010 & 0.010 & 0.010 & 0.010 \\
Sig $^{\text {b }}$ & 0.00 & 0.00 & 0.00 & 0.00 \\
\hline
\end{tabular}

${ }^{\mathrm{a}}$ Under the non-parametric assumption; ${ }^{\mathrm{b}}$ Null hypothesis: true area $=0.5$.

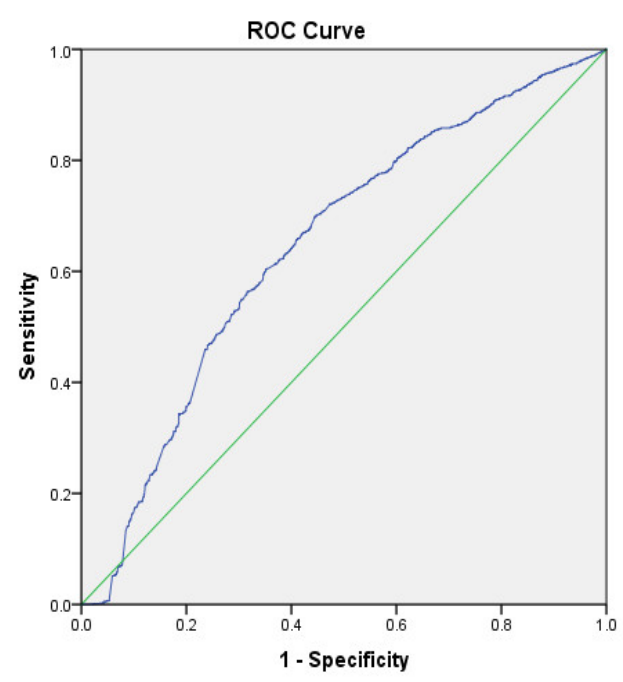

Diagonal segments are produced by ties

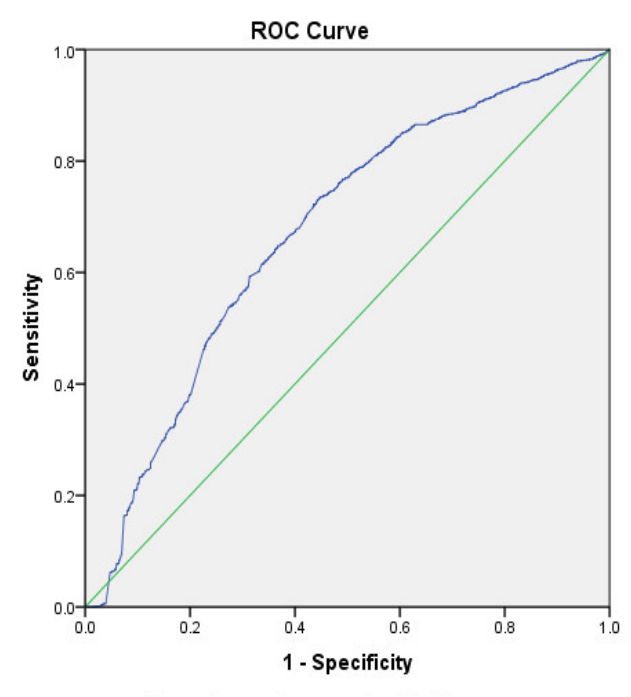

Diagonal segments are produced by ties.

(b). AUC: 0.672; SE: 0.010; Sig:0.00.

(a). AUG: 0.646; SE: 0.010; Sig:0.00.

Figure 2. AUC curve better goodness-of-fit regarding the model as value come under the designated ranges (0.5 to 1.0). (a) ROC curve for subsample 1; (b) ROC Curve for subsample 2. SE stands for standard error and explain the area under nonparametric assumption. Sig stands for level of significance and identify the null hypothesis true area equals to 0.5 . 


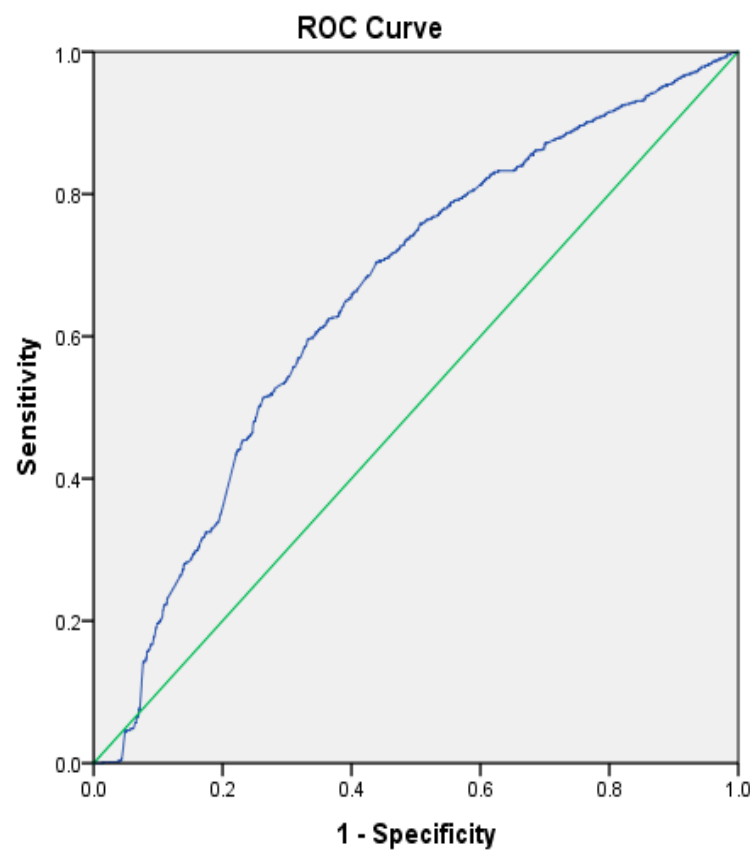

Diagonal segments are produced by ties.

(a); AUC. 0.646; SE: 0.010; Sig: 0.00.

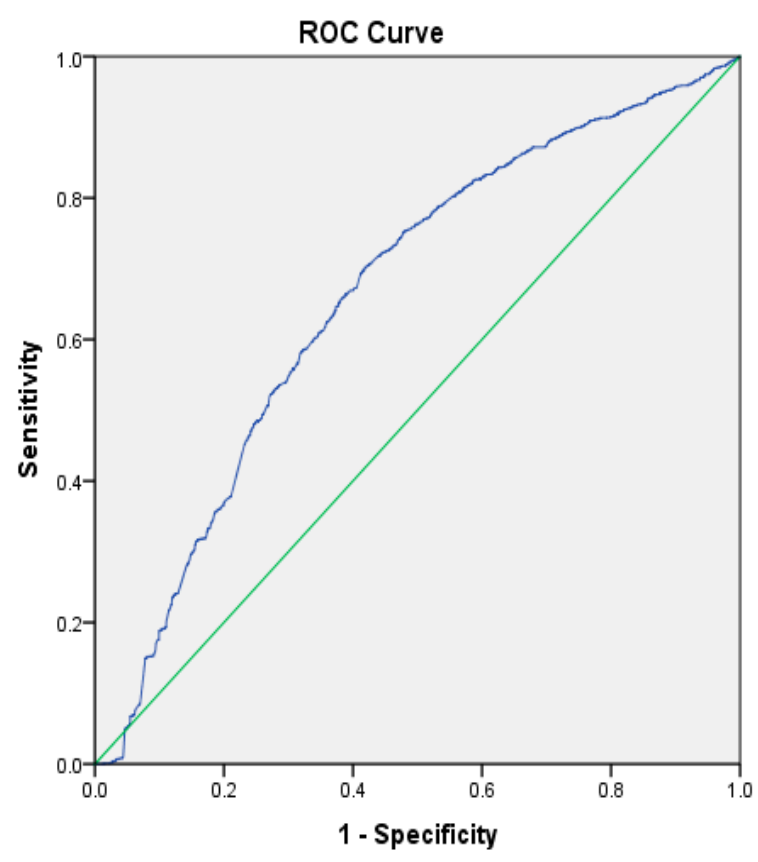

Diagonal segments are produced by ties.

(b) AUG:0.655; SE: 0.010; Sig: 0.00.

Figure 3. AUC curve better goodness-of-fit regarding the model as value come under the designated ranges (0.5 to 1.0). (a) ROC Curve for subsample 3; (b) ROC Curve for subsample 4 . SE stands for standard error and explain the area under nonparametric assumption. Sig stands for level of significance and identify the null hypothesis true area equals to 0.5 . 
Another test used to validate the logistic regression is bootstrapping (see, e.g., [25,82]) by using simple random sampling in order to validate the coefficients of logistic regression. By taking a sample of 1000 with replacements, results from bootstrapping can be seen in Table 6 . The findings in Table 6 are consistent with the original model, the coefficient of media, founders past success, duration, updates, comments, and URL links are highly significant, with media and founders past success strongly affecting the likelihood of success, whereas duration had a negative impact. The $95 \%$ Confidence Intervals (CI) of each coefficient are also relatively narrow.

Table 6. Bootstrap for logistic regression.

\begin{tabular}{ccccccc}
\hline & \multicolumn{3}{c}{ Bootstrap $^{\text {a }}$} & \multicolumn{2}{c}{ 95\% CI } \\
\hline & B & Bias & SE & (2-tailed) & Upper & Lower \\
\hline Media & 0.129 & 0.000 & 0.021 & 0.001 & 0.090 & 0.171 \\
Founders & 0.771 & 0.004 & 0.113 & 0.001 & 0.565 & 0.994 \\
Past Success & & & & & & \\
Duration & -1.854 & -0.002 & 0.094 & 0.001 & -2.039 & -1.665 \\
Updates & 1.533 & 0.004 & 0.080 & 0.001 & 1.391 & 1.705 \\
Comments & 1.637 & 0.002 & 0.055 & 0.001 & 1.529 & 1.747 \\
URL Links & 0.602 & -0.001 & 0.080 & 0.001 & 0.451 & 0.768 \\
Length of & 0.123 & -0.001 & 0.061 & 0.041 & 0.008 & 0.244 \\
Context & & & & & & \\
Constant & 0.562 & 0.002 & 0.221 & 0.015 & 0.112 & 0.978 \\
\hline
\end{tabular}

${ }^{\text {a }}$ Bootstrap based on 1000 samples.

\section{Conclusions, Limitations, and Future Research}

Crowdfunding has introduced a unique challenge and disruptive change in the way it is supporting new financial ventures. This study addresses the importance and influence of quality signals (role of media and founders past success) on crowdfunding success. In such processes, we evaluated the success of three convincing proxies (number of backers, funding amount, and fully funded) which significantly mitigate the problem of information asymmetry and attract the interest of potential backers to invest in a project. Furthermore, we found that the role of media and founders past success are important complements for project success and constitute a strong signal for mitigating the effect of information asymmetry on overall crowdfunding campaigns. Such quality signals boost the interest of potential backers as they can evaluate the project more accurately and effectively before financing a project.

The present findings show that the role of media and founders past success have a positive impact on the likelihood of a successful crowdfunding campaign. Therefore, the higher the signaling, the higher the likelihood of a project reaching the funding goal. Even if both the signals exist in the project, it does not necessarily mean that the project has great appeal because low image quality or excessive use of images will result in a very cluttered project page which could hinder readability and reduce the attractiveness of the initiative. In determining the founder's quality, the size of the founder's digital social network (friends and family), team capabilities, educational background, achievements, and his/her trustworthiness could mitigate information asymmetry and increase the chances of a project being funded successfully.

Moreover, studying the informational mechanisms of crowdfunding platforms supports sustainable development. On one side, projects are floated online but not launched on the market. More or less, it can be seen as receiving preliminary information about the product/service in the shape of feedback from the crowd. In other words, if a crowdfunding project contravenes the notion of sustainable development, it will be rejected from the platform and by the crowd before launching onto the market. On the other hand, lack of financial support is observed as one of the key hurdles that 
deter the sustainable development, whereas, crowdfunding becomes an alternative source of financing in comparison to traditional financing by mitigating the small and medium enterprises (SME's) plight in financing.

We expect that the existing study will stimulate researchers and policy-makers in the development of theory and continue expanding the empirical analysis as regards the role that signaling plays in crowdfunding platforms.

This study has limitations, but it also provides suggestions or recommendations for further research. First, the analyzed data is formed from reward-based projects rather than equity, lending, and patronage models. The backers' understanding and motivations for acting as a lender or philanthropist may be disparate in comparison to equity holders or customers, which results in the occurrence of different success factors. The development of vivid and transparent regulations regarding crowdfunding will generate positive impacts on the decision-making of entrepreneurs and potential backers as well as the operations and functioning of crowdfunding websites. It is suggested that a comparative study of the existing model with other models such as loan, donation, and equity-based crowdfunding can be performed, which will highlight more convincing strategies and performances of crowdfunding.

Second, investigating the role of geography becomes an important area of study for the researchers in the context of crowdfunding. An important feature which differentiates crowdfunding from a conventional source of financing is that it can reduce geographic limitations [19]. Moreover, studying the project's geographical location can influence its chances of success [20]. If data about a project's geographic location is accessible, then a study could be performed which will eradicate distance related frictions and contribute meaningfully to the understanding of crowdfunding.

Third, the peripheral route factors proposed by Bi et al. [23] is one step further in the quality of signals, which can strongly influence the potential backer's investment decision. Word-of-mouth, which is based on the number of reviews and likes about the projects can significantly alter the behaviors of the potential backers. The increasing charm of social media and networking can uplift the significance of this route. This, together with quality signals and peripheral route factors, can help in making a complete outline of success factors in crowdfunding.

Fourth, as a rule, the model generated from logistic regression has a relatively low fitness value due to the limited number of predictor variables which were considered in assessing the success of the campaigns. If more interesting variables are included in the taxonomy of the model, such as measuring the network size by considering the social media channel, gender variable, experience and education of the board members, country preference of industry and product, then it will open up new avenues for further research. It is further suggested that a qualitative study must be conducted in order to study the motivation of the potential investors to finance a project, because some quality signals are more significant than others.

Fifth, regarding crowdfunding policy implication, the rate of fraud in crowdfunding is quite low, but the concept is getting more popular, and it is expected that probabilities of fraud to occur will also increase. According to Mollick [20], the risk of fraud can be reduced by regular interaction of the founders and funders, active contribution, and participation of the local communities, and founders having the ability to present the quality signals of the project through rich descriptions and biographic information. Such acts will play an active role in reducing the rate of fraud and increase the rate of success. Therefore, the related regulative authorities should advertise more comprehensive and detailed rules which could facilitate the founders and backers in reducing the rate of fraud.

Finally, the current research calls for more face-to-face interviews and conducting a survey-based study rather than a web-based secondary data analysis, in order to highlight and develop a sound understanding about information asymmetry that could facilitate and motivate backers in their pledging decision. 
Author Contributions: S.M.U. contributed to the literature review, the conceptualization and writing of the original article and prepared the first draft. All the authors contributed equally to the research design and revised and approved the final manuscript.

Funding: The authors have no funding to report.

Conflicts of Interest: The authors declare no conflict of interest.

\section{References}

1. Amit, R.; Glosten, L.; Muller, E. Entrepreneurial Ability, Venture Investments, and Risk Sharing. Manag. Sci. 1990, 36, 1233-1246. [CrossRef]

2. Evans, D.S.; Leighton, L.S. The Determinants of Changes in U.S. Self-Employment, 1968-1987. Small Bus. Econ. 1989, 1, 111-119. [CrossRef]

3. Li, Y.; Chi, T. Venture Capitalists' Decision to Withdraw: The Role of Portfolio Configuration from a Real Options Lens. Strateg. Manag. J. 2013, 34, 1351-1366. [CrossRef]

4. Badulescu, D.; Simut, R.; Badulescu, A. Looking for Better Financing: A Quantitative Approach on Collateral Importance in SMEs Relationship Lending. In Proceedings of the 8th International Economic Conference on International Days of Statistics and Economics, Prague, Czech Republic, 11-13 September 2014; pp. 43-52.

5. Bruton, G.; Khavul, S.; Siegel, D.; Wright, M. New Financial Alternatives in Seeding Entrepreneurship: Microfinance, Crowdfunding, and Peer-to-Peer Innovations. Entrep. Theory Pract. 2015, 39, 9-26. [CrossRef]

6. Schwienbacher, A.; Larralde, B. Crowdfunding of Small Entrepreneurial Ventures. SSRN Electron. J. 2010. [CrossRef]

7. Xu, L.; Wu, Q.; Du, P.; Qiao, X.; Tsai, S.B.; Li, D. Financing Target and Resale Pricing in Reward-Based Crowdfunding. Sustainability 2018, 10, 1. [CrossRef]

8. Oba, B.; Atakan, S.; Kirezli, O. Value Creation in Crowdfunding Projects-Evidence from an Emerging Economy. J. Innov. Econ. 2018, 26, 37. [CrossRef]

9. Belleflamme, P.; Lambert, T.; Schwienbacher, A. Crowdfunding: Tapping the Right Crowd. J. Bus. Ventur. 2014, 29, 585-609. [CrossRef]

10. Kirmani, A.; Rao, A.R. No Pain, No Gain: A Critical Review of the Literature on Signaling Unobservable Product Quality. J. Mark. 2000, 64, 66-79. [CrossRef]

11. Courtney, C.; Dutta, S.; Li, Y. Resolving Information Asymmetry: Signaling, Endorsement, and Crowdfunding Success. Entrep. Theory Pract. 2017, 41, 265-290. [CrossRef]

12. Jensen, M.C.; Meckling, W.H. Theory of the Firm: Managerial Behavior, Agency Costs and Ownership Structure. J. Financ. Econ. 1976, 3, 305-360. [CrossRef]

13. Ley, A.; Weaven, S. Investigating the Agency Dynamics of Crowdfunding in Start-up Capital Financing. Acad. Entrep. J. 2011, 17, 85-111.

14. Gulati, R.; Higgins, M.C. Which Ties Matter When? The Contingent Effects of Interorganizational Partnerships on IPO Success. Strateg. Manag. J. 2003, 24, 127-144. [CrossRef]

15. Zuckerman, E.W. The Categorical Imperative: Illegitimacy Discount 1. Am. J. Sociol. 1999, 104, 1398-1438. [CrossRef]

16. Hornuf, L.; Schwienbacher, A. Market Mechanisms and Funding Dynamics in Equity Crowdfunding. J. Corp. Financ. 2017, 50, 556-574. [CrossRef]

17. Ahlers, G.K.C.; Cumming, D.; Günther, C.; Schweizer, D. Signaling in Equity Crowdfunding. Entrep. Theory Pract. 2015, 39, 955-980. [CrossRef]

18. Vulkan, N.; Åstebro, T.; Sierra, M.F. Equity Crowdfunding: A New Phenomena. J. Bus. Ventur. Insights 2016, 5, 37-49. [CrossRef]

19. Agrawal, A.; Catalini, C.; Goldfarb, A. The Geography of Crowdfunding. SSRN Electron. J. 2011. [CrossRef]

20. Mollick, E. The Dynamics of Crowdfunding: An Exploratory Study. J. Bus. Ventur. 2014, 29, 1-16. [CrossRef]

21. Turan, S.S. Financial Innovation-Crowdfunding: Friend or Foe? Procedia Soc. Behav. Sci. 2015, 195, 353-362. [CrossRef]

22. Zott, C.; Huy, Q.N. How Entrepreneurs Use Symbolic Management to Acquire Resources. Adm. Sci. Q. 2007, 52, 70-105. [CrossRef]

23. Bi, S.; Liu, Z.; Usman, K. The Influence of Online Information on Investing Decisions of Reward-Based Crowdfunding. J. Bus. Res. 2017, 71, 10-18. [CrossRef] 
24. Chen, X.-P.; Yao, X.; Kotha, S. Entrepreneur Passion and Preparedness in Business Plan Presentations: A Persuasion Analysis of Venture Capitalists' Funding Decisions. Acad. Manag. J. 2009, 52, 199-214. [CrossRef]

25. Ngoc, T.N. Crowdfunding in Vietnam: The Impact of Project and Founder Quality on Funding Success; University of Twente: Enschede, The Netherlands, 2017.

26. Shane, S.; Cable, D. Network Ties, Reputation, and the Financing of New Ventures. Manag. Sci. 2002, 48, 364-381. [CrossRef]

27. Stiglitz, J.E. The Contributions of the Economics of Information to Twentieth Century Economics. Q. J. Econ. 2000, 115, 1441-1478. [CrossRef]

28. Gerber, E.M.; Hui, J.S.; Kuo, P.-Y. Crowdfunding: Why People Are Motivated to Post and Fund Projects on Crowdfunding Platforms. In Proceedings of the ACM Conference on Computer Supported Cooperative work, Seattle, WA, USA, 11-15 February 2012; pp. 1-10.

29. Hornuf, L.; Schwienbacher, A. Funding Dynamics in Crowdinvesting. pp. 1-47. Available online: http: / /hdl.handle.net/10419/112969 (accessed on 25 October 2018).

30. Moritz, A.; Block, J.; Lutz, E. Investor Communication in Equity-Based Crowdfunding: A Qualitative-Empirical Study. Qual. Res. Financ. Mark. 2015, 7, 309-342. [CrossRef]

31. Burtch, G.; Ghose, A.; Wattal, S. The Hidden Cost of Accommodating Crowdfunder Privacy Preferences: A Randomized Field Experiment. Manag. Sci. 2015, 61, 949-962. [CrossRef]

32. Gangi, F.; Daniele, L.M. Remarkable Funders: How Early-Late Backers and Mentors Affect Reward-Based Crowdfunding Campaigns. Int. Bus. Res. 2017, 10, 58. [CrossRef]

33. Burtch, G.; Ghose, A.; Wattal, S. An Empirical Examination of the Antecedents and Consequences of Contribution Patterns in Crowd-Funded Markets. Inf. Syst. Res. 2013, 24, 499-519. [CrossRef]

34. Agrawal, A.; Catalini, C.; Goldfarb, A. Are Syndicates the Killer App of Equity Crowdfunding? Calif. Manag. Rev. 2016, 58, 111-124. [CrossRef]

35. Mavlanova, T.; Benbunan-Fich, R.; Koufaris, M. Signaling Theory and Information Asymmetry in Online Commerce. Inf. Manag. 2012, 49, 240-247. [CrossRef]

36. Akerlof, G. The Market for "Lemons": Quality Uncertainty and the Market Mechanism; Oxford University Press: Oxford, UK, 1970.

37. Agrawal, A.; Catalini, C.; Goldfarb, A. Some Simple Economics of Crowdfunding; University of Chicago Press: Chicago, IL, USA, 2014; Volume 14. [CrossRef]

38. Shun, Y.; Guodong, G.; Viswanathan, S. Strategic Behavior in Online Reputation Systems: Evidence from Revoking on Ebay1. MIS Q. 2014, 38, 1033-1056.

39. Wessel, M.E. Crowdfunding: Platform Dynamics under Asymmetric Information. Ph.D. Thesis, Technischen Universität Darmstadt, Darmstadt, Germany, 2016.

40. Tomboc, G.F.B. The Lemons Problem in Crowdfunding. Inf. Technol. Priv. Law 2013, 30, 253-279.

41. Mollick, E.R. Delivery Rates on Kickstarter. SSRN Electron. J. 2015. [CrossRef]

42. Wessel, M.; Thies, F.; Benlian, A. The Effects of Relinquishing Control in Platform Ecosystems: Implications from a Policy Change on Kickstarter; International Conference of Information Systems: Ft. Worth, TX, USA, 2015.

43. Ghazawneh, A.; Henfridsson, O. Balancing Platform Control and External Contribution in Third-Party Development: The Boundary Resources Model. Inf. Syst. J. 2013, 23, 173-192. [CrossRef]

44. Benlian, A.; Hilkert, D.; Hess, T. How Open Is This Platform? The Meaning and Measurement of Platform Openness from the Complementors' Perspective. J. Inf. Technol. 2015, 30, 209-228. [CrossRef]

45. Micheal, S. Job Market Signaling. Q. J. Econ. 1973, 87, 355-374. [CrossRef]

46. Spence, M. Signaling in Retrospect and the Informational Structure of Markets. Am. Econ. Rev. 2002, 92, 434-459. [CrossRef]

47. Stiglitz, J.E. The Theoy of Screening, Education, the Distribution of Income. Am. Econ. Rev. 1975, 65, $283-300$. [CrossRef]

48. Crosetto, P.; Regner, T. It's Never Too Late: Funding Dynamics and Self Pledges in Reward-Based Crowdfunding. Res. Policy 2018, 47, 1463-1477. [CrossRef]

49. Colombo, M.G.; Franzoni, C.; Rossi-Lamastra, C. Internal Social Capital and the Attraction of Early Contributions in Crowdfunding. Entrep. Theory Pract. 2014, 39, 75-100. [CrossRef]

50. Polzin, F.; Toxopeus, H.; Stam, E. The Wisdom of the Crowd in Funding: Information Heterogeneity and Social Networks of Crowdfunders. Small Bus. Econ. 2018, 50, 251-273. [CrossRef] 
51. Hobbs, J.; Grigore, G.; Molesworth, M. Success in the Management of Crowdfunding Projects in the Creative Industries. Internet Res. 2016, 26, 146-166. [CrossRef]

52. Beckman, C.M.; Burton, M.D.; O’Reilly, C. Early Teams: The Impact of Team Demography on VC Financing and Going Public. J. Bus. Ventur. 2007, 22, 147-173. [CrossRef]

53. Gompers, P.; Kovner, A.; Lerner, J.; Scharfstein, D. Venture Capital Investment Cycles: The Impact of Public Markets. J. Financ. Econ. 2008, 87, 1-23. [CrossRef]

54. Burton, M.D.; Sørensen, J.B.; Beckman, C.M. Coming from Good Stock: Career Histories and New Venture Formation. Res. Sociol. Organ. 2002, 19, 229-262.

55. Hsu, D.H. Experienced Entrepreneurial Founders, Organizational Capital, and Venture Capital Funding. Res. Policy 2007, 36, 722-741. [CrossRef]

56. Crowdfunder. Available online: https://www.crowdfunder.co.uk/about-us/ (accessed on 4 December 2017).

57. Rutland, H. $£ 50,000,000$ Raised by the Crowd!Crowdfunder Stories. Available online: https://www. crowdfunder.co.uk/stories/50000000-raised-by-the-crowd/ (accessed on 13 April 2018).

58. Crowdfunder. Crowdfunding-How to Guide; Crowdfunder: Newquay, UK, $2015 . \quad$ Available online: http:/ / www.crowdfunder.co.uk/uploads/Content/cfuk_a4_crowdfunding_for_crowdfunders-vdinteractive.pdf (accessed on 14 April 2018).

59. Dorfleitner, G.; Priberny, C.; Schuster, S.; Stoiber, J.; Weber, M.; de Castro, I.; Kammler, J. Description-Text Related Soft Information in Peer-to-Peer Lending-Evidence from Two Leading European Platforms. J. Bank. Financ. 2016, 64, 169-187. [CrossRef]

60. Lukkarinen, A.; Teich, J.E.; Wallenius, H.; Wallenius, J. Success Drivers of Online Equity Crowdfunding Campaigns. Decis. Support Syst. 2016, 87, 26-38. [CrossRef]

61. Parhankangas, A.; Renko, M. Linguistic Style and Crowdfunding Success among Social and Commercial Entrepreneurs. J. Bus. Ventur. 2017, 32, 215-236. [CrossRef]

62. Lodhia, S. Web Based Social and Environmental Communication in the Australian Minerals Industry: An Application of Media Richness Framework. J. Clean. Prod. 2012, 25, 73-85. [CrossRef]

63. Sun, P.C.; Cheng, H.K. The Design of Instructional Multimedia in E-Learning: A Media Richness Theory-Based Approach. Comput. Educ. 2007, 49, 662-676. [CrossRef]

64. Rockmann, K.W.; Northcraft, G.B. To Be or Not to Be Trusted: The Influence of Media Richness on Defection and Deception. Organ. Behav. Hum. Decis. Process. 2008, 107, 106-122. [CrossRef]

65. Anderson, J.C.; Hernandez, S.; Jessup, E.L.; North, E. Perceived Safe and Adequate Truck Parking: A Random Parameters Binary Logit Analysis of Truck Driver Opinions in the Pacific Northwest. Int. J. Transp. Sci. Technol. 2018, 7, 89-102. [CrossRef]

66. Skirnevskiy, V.; Bendig, D.; Brettel, M. The Influence of Internal Social Capital on Serial Creators' Success in Crowdfunding. Entrep. Theory Pract. 2017, 41, 209-236. [CrossRef]

67. Josefy, M.; Dean, T.J.; Albert, L.S.; Fitza, M.A. The Role of Community in Crowdfunding Success: Evidence on Cultural Attributes in Funding Campaigns to "Save the Local Theater. " Entrep. Theory Pract. 2017, 41, 161-182. [CrossRef]

68. Smith, D.A.; Brame, R. Tobit Models in Social Science Research: Some Limitations and a More General Alternative. Sociol. Methods Res. 2003, 31, 364-388. [CrossRef]

69. Giudici, G.; Guerini, M.; Rossi-Lamastra, C. Reward-Based Crowdfunding of Entrepreneurial Projects: The Effect of Local Altruism and Localized Social Capital on Proponents' Success. Small Bus. Econ. 2018, 50, 307-324. [CrossRef]

70. Lin, T.-C.; Pursiainen, V. Fund What You Trust? Social Capital and Moral Hazard in Crowdfunding. SSRN Electronic J. 2018. [CrossRef]

71. Peter, K. A Guide to Econometrics; Blackwell Publishing: Oxford, UK, 2008; Volume 91.

72. Fong, E.A.; Xing, X.; Orman, W.H.; Mackenzie, W.I. Consequences of Deviating from Predicted CEO Labor Market Compensation on Long-Term Firm Value. J. Bus. Res. 2015, 68, 299-305. [CrossRef]

73. Henderson, A.D.; Fredrickson, J.W. Top Management Team Coordination Needs and Test of the Ceo Pay Gap: A Competitive Economic and Behavioral Views. Acad. Manag. J. 2001, 44, 96-117. [CrossRef]

74. Hair, J.F.; Black, W.C.; Babin, B.J.; Anderson, R.E. Multivariate Data Analysis; Pearson Education Limited: Harlow, UK, 2010. 
75. Liu, L.; Suh, A.; Wagner, C. Empathy or Perceived Credibility? An Empirical Study on Individual Donation Behavior in Charitable Crowdfunding. Internet Res. 2018, 28, 623-651. [CrossRef]

76. Steigenberger, N.; Wilhelm, H. Extending Signaling Theory to Rhetorical Signals: Evidence from Crowdfunding. Organ. Sci. 2018, 29, 529-546. [CrossRef]

77. Cholakova, M.; Clarysse, B. Does the Possibility to Make Equity Investments in Crowdfunding Projects Crowd Out Reward-Based Investments? Entrep. Theory Pract. 2015, 39, 145-172. [CrossRef]

78. Mollick, E.; Nanda, R. Wisdom or Madness? Comparing Crowds with Expert Evaluation in Funding the Arts. Manag. Sci. 2015, 62, 1533-1553. [CrossRef]

79. Boyce, M.S.; Vernier, P.R.; Nielsen, S.E.; Schmiegelow, F.K.A. Evaluating Resource Selection Functions. Ecol. Model. 2002, 157, 281-300. [CrossRef]

80. Coffey, C.S.; Hebert, P.R.; Ritchie, M.D.; Krumholz, H.M.; Gaziano, J.M.; Ridker, P.M.; Brown, N.J.; Vaughan, D.E.; Moore, J.H. An Application of Conditional Logistic Regression and Multifactor Dimensionality Reduction for Detecting Gene-Gene Interactions on Risk of Myocardial Infarction: The Importance of Model Validation. BMC Bioinform. 2004, 5, 49. [CrossRef]

81. Dreiseitl, S.; Ohno-Machado, L. Logistic Regression and Artificial Neural Network Classification Models: A Methodology Review. J. Biomed. Inform. 2002, 35, 352-359. [CrossRef]

82. Steyerberg, E.W.; Harrell, F.E.; Borsboom, G.J.J.; Eijkemans, M.J.; Vergouwe, Y.; Habbema, J.D.F. Internal Validation of Predictive Models. J. Clin. Epidemiol. 2001, 54, 774-781. [CrossRef]

(C) 2019 by the authors. Licensee MDPI, Basel, Switzerland. This article is an open access article distributed under the terms and conditions of the Creative Commons Attribution (CC BY) license (http://creativecommons.org/licenses/by/4.0/). 